\title{
KEBIJAKAN DI ERA PEMERINTAHAN JOKO WIDODO DAN JUSUF KALLA (PERSPEKTIF POLITIK HUKUM DAN AGRARIA)
}

\author{
NI LUH ARININGSIH SARI ${ }^{1)}$, I WAYAN SUWANDA ${ }^{2)}$ \\ Fakultas Hukum UNMAS Denpasar PSDKU Mataram \\ e-mail : ${ }^{1)}$ Liliksari72@Gmail.com, ${ }^{2)}$ wandha@yahoo.com
}

\begin{abstract}
ABSTRAK
Perkembangan politik hukum agraria di Indonesia tidak terlepas dari kebijakan pemerintahan yang berkuasa pada setiap periode pemerintahan. Periode perkembangannya dapat dibagi menjadi 4 \{empat masa yaitu masa kolonial, masa pemerintahan Soekarno, masa pemerintahan Soeharto dan masa Reformasi. Pasca reformasi, beberapa kali pergantian presiden yaitu Habibie, Gusdur, Megawati dan Susilo Bambang Yudoyono kebijakan terhadap pengaturan keagrariaan dan sumber daya alam tidak terlihat secara nyata sebagai implementasi terhadap pelaksanaan Tap MPR No IX / Tahun 2001. Wacana terkait dengan perubahan pengaturan keagrariaan sudah diwacanakan namun tidak terlaksana secara maksimal.Saat ini pemerintahan Indonesia sedang dipimpin oleh Presiden Joko Widodo berupaya untuk melaksanakan perubahan terhadap politik hukum keagrariaan di Indonesia.
\end{abstract}

Kata Kunci : Reforma Agraria sebagai kebijakan keagrariaan masa pemerintahan Joko Widodo

\section{ABSTRACT}

The political development of agrarian law in Indonesia is inseparable from the policies of the ruling government in each period of government. The period of development can be divided into 4 \{four\} periods, namely the colonial period, the Soekarno administration, the Soeharto era and the Reformation period. After the reformation, several presidential changes, namely Habibie, Gusdur, Megawati and Susilo Bambang Yudoyono, policies on the regulation of natural resources and resources are not clearly seen as the implementation of TAP MPR No. IX /2001. Discourse related to changes in diagrammatic arrangements has been discussed but not implemented optimally. At present the Indonesian government is being led by President Joko Widodo trying to implement changes to the political law of diagramming in Indonesia.

Keywords: Agrarian Reform as the administrative policy of Joko Widodo's administration

\section{PENDAHULUAN}

\section{Latar Belakang}

Masalahan politik hukum agraria pada suatu Negara tidak terlepas dari kebijakan pemerintahan yang sedang berkuasa saat itu. Pengertian politik menurut Miriam Budiardjo sebagaimana yang dikutip oleh Bintan Regen Saragih (2006:6) dalam bukunya Politik menjelaskan pengertian politik adalah "bermacammacam kegiatan (seseorang, sekelompok orang, lembaga-lembaga politik) dalam suatu system politik (atau Negara) yang menyangkut proses menentukan tujuan-tujuan dari system itu. Lebih lanjut menjelaskan bahwa untuk melaksanakan tujuan-tujuan itu perlu ditentukan kebijakan-kebijakan umum (public policies)yang menyangkut pengaturan dan pembagian (distribution) atau alokasi (allocation) dari sumber-sumber (resources) yang ada. Jadi pengertian politik dapat dijelaskan sebagai sebuah kebijakan atau tindakan untuk mencapai sebuah tujuan, dan politik hukum pertanahan dapat diartikan sebagai kebijakan atau tindakan yang dilakukan oleh pemerintah berdasarkan peraturan perundang-undangan untuk mencapai sebuah tujuan terkait dengan penataan keagrariaan di Indonesia. 
Demikian juga yang terjadi di Negara kita Indonesia. Perkembangan politik hukum agraria di Indonesia tidak terlepas dari kebijakan pemerintahan yang berkuasa pada setiap periode pemerintahan. Periode perkembangannya dapat dibagi menjadi 4 (empat) masa yaitu masa kolonial, masa pemerintahan Soekarno, masa pemerintahan Soeharto dan masa Reformasi.

Jika dilihat dari pergantian kepimpinan (presiden) di Negara Indonesia, senyatanya tidak hanya berhenti pada masa reformasi, tetapi telah mengalami beberapa kali pergantian Presiden sebagai kepala pemerintahan hingga saat ini masa pemerintahan Joko Widodo dan Jusuf Kalla. Kebijakan pemerintah setelah reformasi dan sebelum pemerintahan Joko Widodo terkait dengan keagrariaan (pertanahan) tidak terlihat secara nyata, hal ini terlihat tidak adanya bentuk nyata perubahan dalam hal pertanahan di Indonesia.Untuk bisa melihat secara nyata bentuk-bentuk kebijakan pemerintah terkait politik hukum pertanahan di Indonesia perlu kiranya dipaparkan politik hukum pertanahan pada masing-masing periode.

Yang awal dikenal dengan nama periode/masa penjajahan, karena Negara Indonesia pernah dijajah oleh Jepang dan Belanda sehingga mempengaruhi juga pada penataan hukum agraria dan sumber daya agraria. Secara umum pada masa ini dikenal dua macam hukum agraria yaitu hukum agraria adat (bersumber dari hukum adat) yang diperuntukkan bagi mereka yang berasal dari golongan bumi putera dan hukum agraria barat (bersumber dari hukum barat misalnya BW) yang diberlakukan bagi golongan Eropah dan Timur Asing.

Masa berikutnya adalah masa pemerintahan Soekarno. Pada masa pemerintahan Soekarno, kebijakan makro ekonominya lebih dititik beratkan pada sektor pertanian dengan mengoptimalkan sumber daya yg ada.Karena basis perekonomian negara dititik beratkan pada sektor pertanian maka dari sinilah kemudian lahir Undang-Undang Pokok Agraria yaitu UU No 5 Tahun 1960. Ketentuan dalam UUPA melihat hubungan negara dengan bumi (tanah dan kekayaan alam yang terkandung di dalamnya) bukan merupakan hubungan kepemilikan tetapi merupakan hubungan penguasaan (Pasal 33 ayat (3) UUD 1945 jo pasal 2 ayat (1) UUPA).

Selanjutnya adalah masa pemerintahan Soeharto. Kebijakan ekonomi makro pemerintah Soeharto lebih menitik beratkan pada sektor industri yang bersifat padat modal. Melalui Undang-Undang penanaman modal asing dan domestik, diharapkan akan banyak investasi yg masuk dan dapat lebih membangkitkan perekonomian. Hanya saja kebijakan seperti ini akan melahirkan berbagai macam peraturan perundangundangan di bidang agraria yang jauh menyimpang dan bertentangan dengan prinsip-prinsip atau nilai-nilai yg terkandung dlm UUPA. Bidang pertambangan dan kehutanan yg pada dasarnya merupakan bagian dari lingkup agraria, yang mestinya dalam pembentukan peraturan perundang-undangannya serta regulasinya harus berdasarkan UUPA, diabaikan begitu saja. Penetapan pengaturan pertambangan dan kehutanan dalam bentuk Undang-Undang Pokok dan bukan dalam bentuk undang-undang, didasari pada keinginan untuk melepaskan kedua bidang ini dalam ruang lingkup UUPA. Jadi bisa dipahami jika materi kedua undangundang pokok tersebut menyimpang dengan apa yang ada di dalam UUPA.

Jatuhnya pemerintahan Soeharto oleh gerakan reformasi, telah menjadi tonggak untuk melakukan tinjauan kritis (review) terhadap peraturan agraria yang dianggap sudah menyimpang karena dipergunakan sebagai instrumen kekuasaan. Tuntutan untuk melakukan reformasi agraria di Indonesia bermuara pada lahirnya Ketetapan MPR RI no IX Tahun 2001 (Tap MPR RI NoIX/2001) tentang Pembaharuan Agraria dan Pengelolaan Sumber Daya Alam.

Dalam Ketetapan MPR tsb dpt dijumpai arah kebijakan sbb :

1. Melakukan pengkajian ulang terhadap berbagai pengaturan perundangan yang berkaitan dengan agraria dalam rangka sinkronisasi kebijakan antar sektor demi terwujudnya peraturan perundangan yang didasarkan pada prinsip pembaharuan agraria dan pengelolaan sumber daya alam;

2. Melaksanakan penataan kembali penguasaan, pemilikan, penggunaan dan pemanfaatan tanah (landreform) yang berkeadilan dg memperhatikan kepemilikan tanah untuk rakyat;

3. Menyelenggarakan pendataan pertanahan melalui inventarisasi dan registrasi penguasaan, pemilikan, penggunaan dan pemanfaatan tanah secara komprehensif dan sistematis dalam rangka pelaksanaan landreform.

4. Menyelesaikan konflik-konflik yang berkenaan dengan sumber daya agraria yang timbul selama ini sekaligus dapat mengantisipasi potensi konflik di masa mendatang guna menjamin terlaksananya penegakan hukum dengan didasarkan atas prinsip Pembaharuan Agraria Dan Pengelolaan Sumber Daya Alam;

5. Memperkuat kelembagaan dan kewenangannya dalam rangka mengemban pelaksanaan Pembaharuan Agraria dan Menyelesaikan konflik-konflik sumber daya alam yang terjadi;

6. Mengupayakan dengan sungguh-sungguh pembiayaan dalam melaksanakan program pembaharuan agraria dan penyelesaian konflik-konflik sumber daya alam yang terjadi. 
Ketetapan MPR RI ini memberikan arti penting bagi peraturan keagrariaan di Indonesia pada masa mendatang mengingat ketentuan tersebut berkedudukan sebagai :

1. Arah kebijakan strategis dalam memberikan pengaturan di bidang agraria sehingga terjadi perubahan terhadap visi dan misi yang terkandung dalam ketentuan agraria yang ada selama ini. Dengan perkataan lain melalui Ketetapan MPR ini telah lahir Politik Hukum Agraria yang lebih manusiawi;

2. Dasar validitas atau keabsahan bagi peraturan hukum agraria di Indonesia. Artinya ketentuan hukum agraria yang ada harus bersumber dan sesuai dengan substansi yang terkandung dalam Tap MPR tersebut.

Pasca reformasi, beberapa kali pergantian presiden yaitu Habibie, Gusdur, Megawati dan Susilo Bambang Yudoyono kebijakan terhadap pengaturan keagrariaan dan sumber daya alam tidak terlihat secara nyata sebagai implementasi terhadap pelaksanaan Tap MPR No IX / Tahun 2001. Wacana terkait dengan perubahan pengaturan keagrariaan sudah diwacanakan namun tidak terlaksana secara maksimal.

Saat ini pemerintahan Indonesia sedang dipimpin oleh Presiden Joko Widodo berupaya untuk melaksanakan perubahan terhadap politik hukum keagrariaan di Indonesia. Apa saja yang telah dilakukan oleh pemerintah dalam perubahan terhadap tatanan pengaturan keagrariaan di Indonesia menjadi kajian dalam tulisan ini.

\section{Rumusan Masalah}

Bagaimanakah kebijakan keagrariaan di era pemerintahan Presiden Joko Widodo dalam perspektif Politik Hukum Agraria?

\section{Tujuan Penelitian}

Tujuan penelitian ini adalah untuk mengetahui bagaimanakah kebijakan keagrariaan di era pemerintahan Presiden Joko Widodo dalam perspektif Politik Hukum Agraria

\section{METODE PENELITIAN}

Jenis penelitian dalam penelitian ini adalah penelitian normatif yaitu penelitian terhadap azas-azas hukum yang terkait dengan politik hukum Pemerintah Indonesia di bidang pertanahan pada masa pemerintahan Presiden Joko Widodo.

Metode pendekatan yang dipergunakan dalam penelitian ini adalah pendekatan perundang-undangan (the statute approach), Pendekatan historis (historical approach), yaitu menguraikan latar belakang/sejarah perkembangan politik hukum agraria dari masa kolonial hingga masa Reformasi. Pendekatan konseptual (conceptual approach) yaitu memanfaatkan pandangan dan pemikiran para ahli yang berkenaan dengan konsep negara hukum, dan pandangan tentang kebijakan politik pemerintahan pada masa berkuasa. Tehnik yang dipergunakan dalam pengumpulan bahan hukum adalah dengan studi dokumen yakni melakukan pengkajian terhadap data kepustakaan (data sekunder) yang relevan dengan obyek penelitian yang meliputi bahan hukum pimer, sekunder dan tersier baik terhadap peraturan perundang-undangan, buku-buku referensi maupun kamus-kamus hukum. Selanjutnya dianalisis secara deskriptif kualitatif.

\section{PEMBAHASAN}

Sejak dilantiknya menjadi Presiden Republik Indonesia pada tahun 2014, Presiden JokoWidodo dan Jusuf Kalla sebagai wakilnya segera menyusun kabinet kerja agar dapat segera melaksanakan program kerja sebagai janji politiknya saat kampanye. Adapun program kerja yang ditawarkan saat kampanye oleh Presiden Joko Widodo saat kampanye dikenal dengan nama Nawacita yaitu Sembilan (9) Program perubahan untuk Indonesia antara lain (Pusbindiklatren.bappenas.go.id/, 29 -April 2017) :

1. Menolak Negara lemah dengan melakukan Reformasi sistem dan penegakan hukum yang bebas korupsi, bermartabat dan terpercaya;

2. Membangun Indonesia dari pinggiran dengan memperkuat daerah-daerah dan desa dalam kerangka Negara Kesatuan; 
3. Memperteguh Kebhinekaan dan Memperkuat Restorasi Sosial Indonesia;

4. Menghadirkan kembali Negara untuk melindungi segenap Bangsa dan memberikan rasa aman pada seluruh warga;

5. Membuat pemerintah tidak absen dengan membangun tata kelola pemerintahan yang bersih, efektif, demokratif, dan terpercaya;

6. Meningkatkan kualitas hidup manusia Indonesia;

7. Mewujudkan kemandirian ekonomi dengan menggerakkan sector-sektor strategis ekonomi domestic;

8. Melakukan revolusi karakter bangsa;

9. Meningkatkan produktivitas rakyat dan daya saing di pasar Internasional.

Dari program kerja yang dikenal dengan Nawacita ini model pemerintahan yang ingin dilakukan oleh Presiden Joko Widodo mirip dengan gaya pemerintahan masa Soekarno dimana keinginan besar Soekarno adalah menginginkan Indonesia menjadi macan asia menjadi Negara besar yang ditakuti oleh Negara-negara lain di dunia. Kedekatan kepada rakyat dengan turun langsung ke masyarakatan didaerah-daerah untuk melihat secara langsung keadaan rakyat dan melihat secara langsung hasil kerja dari para menterinya.Melakukan reformasi sistem dan penegakan hukum adalah bagian dari kebijakan pemerintah dalam bidang hukum untuk memberikan kepastian hukum, keadilan dan kemanfaatan bagi masyarakat. Termasuk di dalamnya adalah penataan terhadap penguasaan tanah dan pengelolaan sumber-sumber agraria (reforma agraria)

Pada intinya pembaharuan agraria (reforma agraria) adalah upaya perubahan structural yang mendasarkan diri pada hubungan-hubungan intra dan antar subjek-subjek agraria dalam kaitan akses (penguasaan dan pemanfaatan) terhadap objek-objek agraria. Namun secara konkret pembaharuan agraria diarahkan untuk melakukan perubahan struktur penguasaan tanah dan perubahan jaminan kepastian penguasaan tanah bagi rakyat yang memanfaatkan tanah dan kekayaan alam yang menyertainya(Ida Nurlinda, $2009: 77)$.

Boedi Harsono (1995:2-3), menyatakan bahwa Undang-Undang Pokok Agraria (UUPA) bukan hanya memuat tentang ketentuan-ketentuan mengenai perombakan Hukum Agraria tetapi juga memuat Program Revolusi dalam bidang agraria yang disebut Agrarian Reform Indonesia yang memiliki tujuan mewujudkan masyarakat yang adil dan makmur berdasarkan Pancasila. Agrarian Reform Indonesia meliputi lima program yaitu : 1. Pembaharuan Hukum Agraria melalui unifikasi hukum yang berkonsepsi nasional dan pemberian jaminan kepastian hukum; 2.Penghapusan hak-hak asing dan konsesi-konsesi kolonial atas tanah; 3. Mengakhiri penghisapan feudal secara berangsur-angsur; 4. Perombakan pemilikan dan penguasaan tanah serta hubungan-hubungan hukum yang bersangkutan dengan pengusahaan tanah dalam mewujudkan pemerataan kemakmuran dan keadilan; 5. Perencanaan persediaan dan peruntukkan bumi, air dan kekayaan alam yang terkandung didalamnya serta penggunaannya secara terencana, sesuai dengan daya dukung dan kemampuannya. Program ke empat lazim disebut program landreform bahkan keseluruhan program Agrarian Reform (Reforma Agraria) disebut program Landreform sehingga muncul sebutan landreform dalam arti sempit dan landreform dalam arti luas.

Tujuan diadakannya landreform adalah : 1 . Untuk menyempurnakan adanya pemerataan tanah. Ada dua dimensi untuk tujuan ini yaitu pertama adanya usaha untuk menciptakan pemerataan hak atas tanah diantara para pemilik tanah. Ini dapat dilakukan melalui usaha yang intensif yaitu dengan redistribusi tanah; kedua adalah mengurangi perbedaan pendapatan antara petani besar dan kecil yang merupakan usaha untuk memperbaiki pendapatan petani secara menyeluruh; 2. Untuk meningkatkan dan memperbaiki daya guna penggunaan tanah (Supriadi, $2007: 263$ )

Tujuan akhir yang hendak dicapai dengan penyelenggaraan landreform berdasarkan Pasal 17 UUPA adalah penggunaan tanah untuk sebesar-besarnya kemakmuran rakyat dalam arti kebahagiaan, kesejahteraan dan kemerdekaan dalam masyarakat dan Negara hukum Indonesia yang merdeka, berdaulat, adil, dan makmur sebagaimana ditetapkan dalam Pasal 2 ayat (2) UUPA (Urip Santoso, 2012 : 212). Pasal 2 TAP MPR No IX/MPR/2001 dinyatakan bahwa Pembaharuan Agraria mencakup suatu proses yang berkesinambungan berkenaan dengan penataan kembali penguasaan, pemilikan, penggunaan dan pemanfaatan sumber daya agraria, dilaksanakan dalam rangka tercapainya kepastian dan perlindungan hukum serta keadilan dan kemakmuran bagi seluruh rakyat Indonesia. TAP MPR No. IX/MPR/2001 telah memberi secercah harapan bagi mereka yang menggantungkan dirinya pada sektor pertanian terutama para petani dan buruh tani, hal ini disebabkan karena sektor pertanian lebih banyak dikorbankan untuk kepentingan sektor lain misalnya sektor industri ( Achmad Sodiki dan Yanis Maladi, 2009 :. 9)

Dengan kembalinya perhatian pemerintahan terhadap perubahan dan perbaikan dalam tata kelola dan tata penguasaan terhadap tanah dan sumber-sumber daya agraria memberikan kepastian hukum terhadap kepemilikan, penguasaan dan pengelolaan terhadap tanah dan suber daya agraria diharapkan dapat 
meningkatkan kesejahteraan rakyat. Karena selama ini konflik keagrariaan menjadi sangat tidak terkendali dikarenakan perhatian pemerintah sebelumnya terhadap perkembangan keagrariaan khususnya terhadap hakhak rakyat dan masyarakat adat terhadap tanah sangat kurang bahkan terkesan diabaikan. Dengan Nawacita pemerintahan Joko Widodo ingin melaksanakan kembali program Reforma Agraria untuk menegakkan kembali hukum di bidang keagrariaan sehingga memberikan kepastian hukum terhadap kepemilikan dan penguasaan hak terhadap tanah dan pengelolaan sumber daya alam.

Empat (4) tahun masa pemerintahan Presiden Joko Widodo sebagaimana yang termuat dalam Laporan 4 Tahun Pemerintahan Joko Widodo - Jusuf Kalla, pemerintah mengakselerasi pelaksanaan Reforma Agraria dan Perhutan Sosial untuk mewujudkan keadilan social dalam penguasaan, penggunaan, dan pemanfaatan tanah, wilayah dan sumber daya alam dilakukan melalui paket kebijakan Reforma Agraria dan Perhutan Sosial (http://www.bkkbn.go.id/po-content/uploads/Laporan-4-tahun-Jokowi-JK)

Di dalam proses pelaksanaan kebijakan ini pemerintah terlebih dahulu menyiapkan payung hukum terkait dengan kawasan hutan dan reforma agraria yaitu :

1. Perpres No 88 Tahun 2017 Tentang Penyelesaian Penguasaan Tanah Dalam Kawasan Hutan (PPTKH);

2. Perpres No 86 Tahun 2018 Tentang Reforma Agraria;

3. Inpres No 8 Tahun 2018 Tentang Penundaan dan Evaluasi Perizinan Perkebunan dan Peningkatan Produktivitas Perkebunan Kelapa Sawit.

Menurut sumber dari Kementeriaan Agraria dan Tata Ruang/Badan Pertanahan Nasional (ATR/BPN) total capaian Reforma Agraria sampai dengan Oktober 2018 adalah 9.491 .557 bidang sedangkan Perhutanan Sosial yang terealisasi $2.007 .557,81$ ha yang terdiri dari 298.304,74 ha hutan tanaman rakyat, 490.367,60 ha hutan kemasyarakatan dan 27.950,34 ha hutan adat. Reforma Agraria dan Perhutanan Sosial bertujuan untuk memberikan hak dan akses lahan kepada masyarakat kurang mampu. Jika dilihat dari angka pencapaian Perhutanan Sosial pada hutan adat masih sangat kecil dibandingkan dengan hutan tanaman rakyat dan kemasyarakatan. Menjadi sebuah kajian selanjutnya terhadap permasalahan hutan adat di Indonesia.

Dalam hal penanganan konflik Reforma Agraria pemerintah terus berupaya untuk menyelesaikan konflik/sengketa agraria sejalan dengan melakukan legalisasi/sertifikasi lahan yang sah clean dan clear. Penanganan konflik Reforma Agraria sebagaimana data yang diperoleh dari Kementerian Agraria dan Tata Ruang/Badan Pertanahan Nasional (ATR/BPN) yaitu :

Tabel 1. Jumlah Sengketa Tanah dan yang Sudah Diselesaikan Tahun 2015-2018

\begin{tabular}{|c|c|c|}
\hline TAHUN & JUMLAH SENGKETA & YANG SELESAI \\
\hline 2015 & 2.145 & 947 \\
\hline 2016 & 2.996 & 1.570 \\
\hline 2017 & 3.293 & 1.034 \\
\hline 2018 & 2.368 & 480 \\
\hline
\end{tabular}

Sumber : Kementerian Agraria dan Tata Ruang/Badan Pertanahan Nasional (ATR/BPN)

Dalam pelaksanaan legalisasi/sertifikasi lahan bertujuan untuk memberikan kepastian hukum terhadap kepemilikan hak atas tanah. Disamping itu pembagian sertifikasi tanah gratis melalui program Pendaftaran Tanah Sistematis Lengkap (PTSL) merupakan program Presiden Joko Widodo untuk menyisir seluruh wilayah terdata melalui mekanisme sertifikasi secara keseluruhan. Langkah ini dikatakan efektif untuk mengejar target 126 juta bidang tanah di tahun 2024 sudah bersertifikat. (https://finance.detik.com/properti/d3937118/Alasan-Jokowi-Bagi-Sertifikat-Tanah-Gratis, Senin 26 Maret 2018).

Namun demikian menurut Konsorsium Pembaharuan Agraria (KPA) menilai program Reforma Agraria yang dijalankan pemerintahan Joko Widodo - Jusuf Kalla masih belum berjalan dengan baik. KPA menilai tahapan Redistribusi Tanah dalam Reforma Agraria masih belum sesuai dengan target yang telah ditetapkan yaitu 400 ribu ha tanah untuk di redistribusikan kepada Subyek tanah prioritas yakni Petani,Buruh Tani, Nelayan dan Masyarakat yang terdampak konflik agrarian. Berdasarkan data Kementerian Agraria dan Tata Ruang /Badan Pertanahan Nasional (ATR/BPN) baru 270.237 ha lahan yang telah berhasil di redistribusi (Dimas Jarot Bayu,dalam https://kata.data.co.id/berita/2019/03/04/Kpa-nilai-reforma-agraria-diera-jokowi-belum-sesuai-target).

Konsorsium Pembaharuan Agraria (KPA) berharap bahwa Reforma Agraria tidak hanya dijalankan oleh Kementerian Koordinator Bidang Perekonomian, Kementerian ATR/BPN serta Kementerian Lingkungan Hidup dan Kehutanan tetapi juga perlu keterlibatan dari berbagai kementerian/lembaga lain 
untuk menuntaskan program Reforma Agraria seperti BPK, Kemenkeu, MA, Kejaksaan, Kepolisian, termasuk DPR.

Keseriusan pemerintahan Joko Widodo di dalam pelaksanaan Reforma Agraria terlihat dari disusunnya buku panduan yang menjadi rujukan bagi pelaksanaan Reforma Agraria yang menjadi arahan bagi penyusunan Prioritas Nasional Reforma Agraria sebagaimana tercantum dalam Rencana Kerja Pemerintah tahun 2017 yang mencakup lima komponen yakni :

1. Penguatan kerangka Regulasi dan Penyelesaian Konflik Agraria, yang ditujukan untuk menyediakan basis regulasi yang memadai bagi pelaksanaan agenda-agenda reforma agraria dan menyediakan keadilan melalui kepastian tenurial bagi tanah-tanah masyarakat yang berada dalam konflik - konflik agraria;

2. Penataan penguasaan dan pemilikan tanah obyek Reforma Agraria, yang ditujukan untuk mengidentifikasi subyek penerima, dan objek tanah - tanah yang akan diatur kembali hubungan penguasaan dan kepemilikannya;

3. Kepastian hukum dan legalisasi hak atas tanah obyek Reforma Agraria yang ditujukan untuk Hak atas tanah objek Reforma Agraria, yang ditujukan untuk memberikan kepastian hukum dan penguatan hak dalam upaya mengatasi kesenjangan ekonomi dengan meredistribusikan lahan menjadi milik rakyat;

4. Pemberdayaan masyarakat dalam penggunaan, pemanfaatan dan produksi atas tanah objek Reforma Agraria, yang ditujukan untuk mengurangi kemiskinan dengan perbaikan tata guna dan pemanfaatan lahan, serta pembentukan kekuatan-kekuatan produktif baru;

5. Kelembagaan pelaksanaan Reforma Agraria Pusat dan Daerah untuk memastikan tersedianya dukungan kelembagaan di Pemerintah Pusat dan Daerah, serta memampukan desa untuk mengatur penguasaan, pemilikan, penggunaan dan pemanfaatan tanah, sumber daya alam, dan wilayah kelola desa.

Setiap komponen program dilaksanakan dengan berdasar pada prinsip-prinsip utama yakni :

1. Keadilan yaitu bahwa program Reforma Agraria dilakukan untuk memberikan keadilan akses penguasaan, pemanfaatan, penggunaan dan pemilikan hak atas tanah yang sama bagi setiap warga Negara;

2. Keberlanjutan yaitu pelaksanaan Reforma Agraria dilakukan dengan memperhatikan daya dukung ekosistem di setiap lokasi;

3. Sinergitas yaitu terbangunnya sinergi, koordinasi, dan kerjasama yang profesional berdasarkan tugas dan fungsi masing-masing institusi dan lembaga terkait;

4. Pemberdayaan yaitu program Reforma Agraria dilakukan untuk meningkatkan kemampuan pelaksanaan di pusat maupun di daerah dalam melaksanakan tugasnya masing-masing dan bagi penerima manfaat dalam rangka meningkatkan kualitas hidupnya lebih baik;

5. Kesetaraan hak berdasarkan gender yaitu program Reforma Agraria dilakukan harus memperhatikan hakhak sama antara perempuan maupun laki-laki dalam mengakses sumber-sumber daya agraria baik dalam konteks penguasaan, pemanfaatan, penggunaan maupun pemilikan hak atas tanah.

Program Reforma Agraria yang dilaksanakan oleh pemerintahan JokoWidodo sebagaimana janji politik dalam Pilpres 2014 telah dilaksanakan walaupun belum berjalan dengan baik jika dibandingkan dengan kebijakan-kebijakan pemerintahan sebelumnya yang belum bahkan bisa dikatakan tidak memiliki perhatian yang serius terkait dengan reforma agraria. Pelaksanaan program Reforma Agraria yang belum bisa dilaksanakan dengan maksimal namun capaian dalam 4 tahun kinerja pemerintahan Joko Widodo telah memberikan angin segar dalam perubahan kebijakan politik hukum agraria di Indonesia.

Selama 4 tahun masa pemerintahannya Joko Widodo telah melaksanakan Reforma Agraria dalam hal redistribusi tanah, legalisasi/sertifikasi tanah dan menyelesaikan konflik-konflik agraria. Pencapaian ini adalah sebuah prestasi dibandingkan dengan beberapa periode pemerintahan sebelumnya. Penyelesaian konflik-konflik keagrariaan memang tidak bisa serta merta dalam jangka waktu 4 tahun bisa diselesaikan/dituntaskan mengingat konflik/permasalahan keagrariaan ini merupakan warisan dari jaman penjajahan dan ditambah dengan konflik-konflik keagrariaan pada masa Soeharto yang belum bisa diselesaikan oleh pemerintahan selanjutnya hingga pemerintahan saat inilah yang mulai membenahi tatanan keagrariaan di Indonesia dalam kebijakan politiknya. 


\section{SIMPULAN DAN SARAN}

\section{Simpulan}

Bahwa dengan program kerja pemerintahan Joko Widodo - Jusuf Kalla yang dikemas dalam Nawacita khususnya dalam hal kebijakan keagrariaan, Presiden Joko Widodo melaksanakan kembali program Reforma Agraria yaitu pelaksanaan redistribusi tanah, penataan kembali kepemilikan, penguasaan dan pengelolaan agraria, serta penyelesaian konflik-konflik keagrariaan.

\section{Saran-saran}

Pencapaian yang belum maksimal sesuai dengan target yang ditetapkan hendaknya dilakukan evaluasi secara utuh menyeluruh baik dalam hal sumber daya manusia yang melaksanakan Reforma Agraria, regulasi yang belum menyentuh hingga masyarakat bawah dan sinergisitas antar lembaga pemerintahan yang belum bersama-sama ikut serta dalam membantu pelaksanaan Reforma Agraria sebagai program nasional pemerintah.

\section{DAFTAR PUSTAKA}

\section{Buku}

Achmad Sodiki dan Yanis Maladi,2009. Politik Hukum Agraria,, Mahkota Kota Yogyakarta

Boedi Harsono, 1995. Hukum Agraria Indonesia Jilid 1, Djambatan, Jakarta

Bintan Regen Saragih, 2006. Politik Hukum, Penerbit CV. Utomo Bandung.

Ida Nurlinda, Prinsip-Prinsip Pembaharuan Agraria Perspektif Hukum, Rajawali Pers, Jakarta 2009

Supriadi, 2007. HukumAgraria, Sinar Grafika Jakarta

Urip Santoso, 2012. Hukum Agraria Kajian Komprehensif, Kencana Jakarta.

\section{Peraturan Perundang-undangan}

Undang-Undang Dasar Negara Republik Indonesia Tahun 1945

TAP MPR RI NO IX Tahun 2001 Tentang Pembaharuan Agraria Dan Pengelolaan Sumber Daya Alam

Undang-Undang No 5 Tahun 1960 Tentang Undang-Undang PokokAgraria

\section{Internet}

Pusbindiklatren.bappenas.go.id/file/bukuterbit/SIMPUL Vol 29-April 2017

http://www.bkkbn.go.id/po-content/uploads/Laporan-4-tahun-Jokowi-JK

https://finance.detik.com/properti/d-3937118/Alasan-Jokowi-Bagi-Sertifikat-Tanah-Gratis, Senin 26 Maret 2018 ,

https://kata.data.co.id/berita/2019/03/04/Kpa-nilai-reforma-agraria-di-era-jokowi-belum-sesuai-target

Pelaksanaan Reforma Agraria. Arahan kantor staf Presiden : Prioritas Nasional Reforma Agraria Dalam Rencana Kerja Pemerintah, kpa.or.id/publikasi/.../ac891-strategi-nasional-reforma-agraria pdf, 1 September 2017. 